\title{
Chapter 31 \\ Towards an Arctic Awakening: Neocolonalism, Sustainable Development, Emancipatory Research, Collective Action, and Arctic Regional Policymaking
}

\author{
Ulunnguaq Markussen
}

\begin{abstract}
The Arctic is increasingly subject to processes of global change, presenting new challenges to Arctic peoples. As the world becomes more aware of the importance of the Arctic, the concept of Arctic risk is becoming globalised, advancing technocratic discourses and solutions that suit metropolitan (rather than Arctic) interests. Arctic peoples require knowledge, research, and resources from outside the region yet must take care to avoid economic, educational, and political neocolonialism operating under the disguise of sustainable development. The changing Arctic, however, offers Arctic peoples new opportunities for collective action. We recommend a form of Arctic regional policymaking that works across multiple channels and levels of formality to foster genuine sustainable development that meets the needs of all Arctic peoples. Such collective action should reach across and beyond state borders, bringing together Indigenous peoples and other Arctic communities, as well as cultivating awareness of shared interests through emancipatory research and education.
\end{abstract}

The Arctic is changing, whether we like it or not.

Changes in the region's environmental, technological, cultural, and political conditions pose new challenges but also new opportunities. These are rooted in part how we - as the peoples of the Arctic - respond to change. We who have the greatest stake in the region must likewise take the lead in this new era, help form and formulate Arctic futures that serve the needs of our communities, cultures, environments, economies, and wellbeing. The peoples of the Arctic are awakening to the positive potential for change. In this chapter, 'peoples of the Arctic' and 'Arctic peoples' refers to both Indigenous and non-Indigenous communities residing in the Arctic

U. Markussen $(\bowtie)$

Ilisimatusarfik/University of Greenland, Nuuk, Greenland

e-mail: ulum@uni.gl 
region. This diverges from the state-centric perspective (such as that operating within the Arctic Council), which privileges the interests of 'Arctic states' even though the dominant political actors in most such states are not themselves based in the Arctic.

Climate change means melting sea ice, thawing permafrost and, more generally, changing local and regional conditions. These changes will produce both positive and negative effects in the Arctic, from increased navigability of arctic waters to decreased ability to engage in traditional livelihoods. Similarly, the spread of information technology is offering Arctic peoples the possibility not only to learn about developments in the wider world but also to reach out directly to allies across the region and farther afield, thereby bypassing existing communicational intermediaries in the metropolitan centre. By the same token, however, this increased openness and cultural porosity may enhance the power of detrimental demonstration effects, leading to culture loss and greater assimilation into metropolitan society. In addition, the very political structures through which societies have managed change over the past four centuries are themselves undergoing considerable change, as the power of the sovereign state is challenged by growing local, regional, supranational, and global policymaking on the one hand and governance incursions by transnational corporate actors on the other. Some Arctic peoples risk losing the shelter and support of the metropole ${ }^{1}$ At the same time, the Arctic peoples have the potential to embrace new opportunities for collective political action and policy innovation.

\subsection{Against Neocolonialism}

We have become increasingly attuned to the necessity of asserting our rights when dealing with transnational corporations and powerful state actors, and such actors have in turn become increasingly aware of the necessity of taking our rights into account (Wilson 2016; Papillon and Rodon 2017). Foreign capital and expertise is not in itself bad, but it is vital to ensure that foreign-led and financed economic activities in the Arctic serve the needs of Arctic peoples as well in order to prevent becoming caught up in neocolonial processes. From mining companies and fishing interests to government authorities based in distant seats of power, we must seek to simultaneously be open to the world and avoid becoming a passive cog in the great machine of global capital and realpolitik.

The globalisation of corporate power is accompanied by a globalisation of risk and of concern for Indigenous peoples and the future of the Arctic. As the world awakens to the dangers of climate change, increasing attention is being paid to scientific research into the Arctic, research that - though often well-meaning - is also often embedded in metropolitan mindsets, which ultimately reinforce existing

\footnotetext{
${ }^{1}$ The metropolitan power; the power centre within the centre-periphery relationships at work in a given polity, such as Denmark relative to Greenland, Moscow relative to the Russian Arctic, or indeed the institutions and processes controlled by such centres of power.
} 
power structures, priorities, and dependencies. Each new scientific report produced from the metropole highlights new challenges for Arctic peoples while advancing ever-more technocratic discourses and globalist solutions. People the world over are at last becoming aware of how important the Arctic is to them, yet this growing recognition is not guaranteed to result in greater influence for Arctic peoples; it might just as easily result in renewed metropolitan efforts to control developments in the region to suit state or globalist interests - perhaps at the expense of those who make the Arctic their home. Indeed, international focus on climate change may in some cases be politically convenient for powerful actors rather than ideally suited for improving the lives of those in the affected regions (Kelman et al. 2015; Baldacchino and Kelman 2014).

We require knowledge, research, and resources from outside the region if we are to undertake sustainable development and take advantage of the changing conditions. However, care must be taken to avoid buying into or submitting to a neocolonialisation of the Arctic. Images of melting glaciers and starving polar bears may galvanise the wider public and power holders to action in a manner that is not beneficial to Arctic peoples.

The peoples of the Arctic are not responsible for having produced global environmental threats, yet metropolitan society calls upon us to forego economic development and extractive industries, take symbolic action against global challenges, and stand at the vanguard of a new era of 'conspicuous sustainability' (Grydeh $\varnothing j$ and Kelman 2016). Such efforts to persuade us to turn our lands and seas into nature preserves, to transform our traditional territories into a form of World Heritage and present the Arctic as a treasure belonging equally to the world as a whole, are ultimately requests that we who have been so long exploited and so thoroughly dispossessed further sacrifice ourselves for the continued wellbeing of those who have proven unwilling to make sacrifices. Effective efforts to preserve Arctic environments and revitalise Arctic livelihoods should take precedence over symbolic action and 'conspicuous sustainability' that provides little real benefit (Grydehøj and Kelman 2016). We do not ask to live from the charity of metropolitan benefactors. We do not wish to be the realisation of metropolitan visions of happy, hardy Northerners in need of patronage from the forces of global capital. The last thing we want is to be a canary in the coalmine, a cautionary tale (Farbotko 2010).

\subsection{A New Era of Arctic Cooperation}

If we are to guide change in the Arctic rather than merely become victims of it or take on roles designed to appeal to metropolitan sensibilities, it is necessary to accept that change is occurring and then commit to managing it. The Arctic is home to many peoples, who possess diverse sets of needs. Yet we are united by a number of shared - if not universal - interests, which can be supported through collective action, whether through formal bodies that can engage with sovereign states or through looser, more flexible coalitions of actors. What is clear is that Arctic 
sustainability depends on long-term governance across national borders transcending single state, corporate, or even ethnic interests, in light of the remarkable interdependence of Arctic peoples and environments surrounding their shared sea.

As Arctic peoples, we must identify what we really want so that we can begin setting common targets, planning for and implementing strategic actions, and taking on strategic responsibilities. By creating a true Arctic community, one that works at multiple levels of formality and through multiple channels, we can at last truly gain a voice (Plaut 2012). An openness to informal political organisation must complement a dedication to constructing strong institutional foundations for Arctic policymaking that reflects shared values and priorities. As we work to define our own ethnic and national identities, we should seek to locate these within a wider Arctic identity, one that can enrich - rather than overshadow - our localised values. Such a multifaceted, pan-Arctic policymaking platform could strengthen our ability to engage with non-Arctic actors (including metropolitan interests within states that possess Arctic territory), which are both affecting and affected by changes taking place within the Arctic. This contrasts with current regional bodies and institutions, which often take a broad state-centric perspective (for example, the Arctic Council and the Barents Euro-Arctic Council) or a narrow focus on Indigenous interests (for example, the Inuit Circumpolar Council and the Indigenous Peoples' Secretariat): Both such perspectives are necessary and important, but the former places agency in the hands of the metropole while the latter risks creating false divisions between Arctic communities, erroneously grouping the interests of Arctic non-Indigenous peoples with those of the metropole.

Arctic economic, societal, cultural, and political development must be led by Arctic peoples themselves, working to develop peaceful and constructive relationships at the community, state, and other levels. A sense of a shared stake in the Arctic can even help foster better relationships between Indigenous peoples and former colonisers, supporting a decolonial Arctic politics that regards all Arctic peoples as equal - understanding the consequences of historic injustice without perpetuating ethnic and political animosity. Understanding today's Arctic and envisioning a future Arctic requires acknowledgment that, across much of the North, "the institutional and ideological interference of the colonial period directly or indirectly, subtly or overtly, continues to influence political thought and economic agendas" (Nadarajah and Grydehøj 2016: 442; see also Grydehøj 2016).

These must not, however, be decisions made by a local elite. It is important that the entire population of the Arctic be involved in the move toward sustainable regional development and come to understand the benefits to collective action and collective development. At the same time, desired development outcomes must be localised; no longer can it be acceptable for Arctic actors to pursue competitive, zero-sum games against one another. At the same time, as we recognise that shared development may require certain shared sacrifices, we must draw the line at sacrificing some communities solely in favour of others. 


\subsection{Arctic Research and Education}

This kind of regional awareness and bottom-up policymaking requires enhanced knowledge on the part of Arctic peoples and an improved connection between science and policymaking. Education is key to this, with actors such as UArctic working to build local capacity through education. Yet it is important to be conscious of neocolonial forces within education systems and to prevent the development of an Arctic cultural elite that is distanced from knowledge of ordinary communities across the region. Development planning is increasingly driven by systemitisation, data collection, and technocratic discourses, which often combine to privilege metropolitan interests and expertise, leading to local suspicion of development and planning in general (Pugh 2013, 2016).

Without denying the importance of 'evidence-based policymaking', it is necessary to recognise that, in today's world, not all kinds of evidence are treated equally. In particular, the experiences of Arctic Indigenous peoples, who have centuries or millennia of experience living in close interaction with nature, can contribute lessons in flexible livelihoods and adaptability to harsh and changing environments (e.g. Pearce et al. 2015). Climate change, for example, will have serious and possibly even disastrous repercussions in some parts of the world, but this change will need to be dealt with, and its effects on Arctic environments and peoples may not be straightforwardly negative. It is vital that Arctic policy breaks free from the crippling strictures of neoliberal risk, vulnerability, and resilience discourse (Evans and Reid 2014). Scientific research and evidence-based policymaking that is sensitive to Arctic conditions may reach quite different conclusions than research and policymaking with a metropolitan orientation. The scientifically and technocratically motivated drive toward 'modernisation' asks Arctic Indigenous peoples to submit to a developmental model that has proved environmentally calamitous on the global scale and that has been applied elsewhere with such poor results in earlier periods of decolonisation. Involvement of Arctic peoples in Arctic research is a necessary but insufficient condition for truly locally oriented research: The framework, expectations, and design of the research must itself be decolonised.

Arctic peoples require an emancipatory and decolonial system of research and education, which neither turns its back on knowledge and cutting-edge scholarship nor find itself trapped in preconceived notions regarding the creation of colonial (or postcolonial) subjects. Scientific research itself - from the humanities, social sciences, and natural sciences - should be undertaken by or in close engagement with people from a diverse range of communities, who can both contribute their own perspectives to the wider scientific world and better communicate findings to their own communities (Mulligan and Nadarajah 2008). Greater investment in Arctic science is critical for achieving Arctic sustainability - but only if this science has firm roots in Arctic communities. 
Arctic peoples share a number of cultural values but also possess cultural distinctions from one another, which produces a rich seam of traditional and Indigenous knowledge that can be drawn upon in developing Arctic research and education. Truly Arctic research and education does not involve rejecting science or Western learning; it instead involves the investment of such knowledge with local values in order to better serve local needs. To paraphrase Grant McCall (1994), Arctic studies must consider Arctic peoples on their own terms, not on those of metropolitan wellwishers, development workers, or political authorities.

\subsection{Towards an Arctic Awakening}

Global change is producing new challenges for peoples of the Arctic, but it is also bringing us closer together. We cannot simply draw the line at the individual community, ethnic group, nation, or even state: It is vital for us all to get engaged with the shared Arctic project. By grasping the necessity of change, we can enter a new era of regional stability, shared purpose, and political power.

Change is coming. We may find it daunting, yet it is up to us, the peoples of the Arctic, to say: We will no longer be passive observers of our development but will take charge of our futures.

We belong to the Arctic, and the Arctic belongs to us.

Acknowledgements I would like to thank Adam Grydehøj, my respectful mentor, for his valuable support and contribution on this chapter.

\section{References}

Baldacchino G, Kelman I (2014) Critiquing the pursuit of island sustainability: blue and green, with hardly a colour in between. Shima 8(1):1-21

Evans B, Reid J (2014) Resilient life: the art of living dangerously. Polity, Cambridge/Malden

Farbotko C (2010) Wishful sinking: disappearing islands, climate refugees and cosmopolitan experimentation. Asia Pac Viewpoint 51(1):47-60

Grydehøj A (2016) Navigating the binaries of island independence and dependence in Greenland: decolonisation, political culture, and strategic services. Polit Geogr 55:102-112

Grydehøj A, Kelman I (2016) The eco-island trap: climate change mitigation and conspicuous sustainability. Area

Kelman I, Gaillard JC, Mercer J (2015) Climate change's role in disaster risk reduction's future: beyond vulnerability and resilience. Int J Disast Risk Sci 6(1):21-27

McCall G (1994) Nissology: a proposal for consideration. J Pac Soc 17(2-3):1-8

Mulligan M, Nadarajah Y (2008) Working on the sustainability of local communities with a 'community-engaged' research methodology. Local Environ 13(2):81-94

Nadarajah Y, Grydehøj A (2016) Island studies as a decolonial project. Island Stud J 11(2):437-446

Papillon M, Rodon T (2017) Proponent-Indigenous agreements and the implementation of the right to free, prior, and informed consent in Canada. Environ Impact Assess Rev 62:216-224 
Pearce T, Ford J, Willox AC, Smit B (2015) Inuit ecological knowledge (TEK), subsistence hunting and adaptation to climate change in the Canadian Arctic. Arctic 68(2):233-245

Plaut S (2012) 'Cooperation is the story'-best practices of transnational indigenous activism in the North. Int J Human Rights 16(1):193-215

Pugh J (2013) Speaking without voice: participatory planning, acknowledgment, and latent subjectivity in Barbados. Ann Assoc Am Geogr 103(5):1266-1281

Pugh J (2016) Postcolonial development, (non)sovereignty and affect: living on in the wake of Caribbean political independence. Antipode

Wilson E (2016) What is the social licence to operate? local perceptions of oil and gas projects in Russia's Komi Republic and Sakhalin Island. Extract Indust Soc 3(1):73-81

Open Access This chapter is licensed under the terms of the Creative Commons Attribution 4.0 International License (http://creativecommons.org/licenses/by/4.0/), which permits use, sharing, adaptation, distribution and reproduction in any medium or format, as long as you give appropriate credit to the original author(s) and the source, provide a link to the Creative Commons license and indicate if changes were made.

The images or other third party material in this chapter are included in the chapter's Creative Commons license, unless indicated otherwise in a credit line to the material. If material is not included in the chapter's Creative Commons license and your intended use is not permitted by statutory regulation or exceeds the permitted use, you will need to obtain permission directly from the copyright holder.

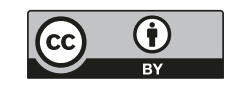

